\title{
The Effectiveness of Video Presentation Techniques on Learning of Security Studies Concepts in International Relations Department of Universitas Andalas Indonesia
}

\author{
Zulkifli Harza ${ }^{1, *}$ Maryam Jamilah ${ }^{2}$ \\ ${ }^{I}$ International Relations Department, Universitas Andalas, West Sumatra, Indonesia \\ ${ }^{2}$ International Relations Department, Universitas Andalas, West Sumatra, Indonesia \\ ${ }^{*}$ Corresponding author. Email: zharza@soc.unand.ac.id
}

\begin{abstract}
Security study is one main course in the international relations discipline because it consists of an important conceptual framework that is crucial in understanding the relationship between states and global politics. Previous learning method which has applied to this course demand domination of lecturers and face to face in every learning process. Meanwhile, in the current era of technological development, the world demands a flexible type of learning in terms of time, place, and circumstances. This article examines the effectiveness of video presentation techniques on learning security studies concepts. The population of this study is a student of the international relations department Universitas Andalas who enrolls in the security studies course this semester. The technique of data collection is by using questioner, pre-test and post-tests. This study found that by applying a video presentation technique $88 \%$ of students agree that it helps them in understanding basic concepts of security (deterrence, nuclear proliferation, security dilemma, warfare, bandwagoning, buck-passing, International Cooperation, dependency, interdependency, dan arm race). Based on the post test more than $58 \%$ of students present maximum grade, it indicates the effectiveness of video presentation techniques on learning of security concepts.
\end{abstract}

Keywords: Video presentation technique, Security studies, International relations, Learning method

\section{INTRODUCTION}

The security course is one of the main courses in international relations because it provides insights and understanding of both domestic and global order, and the stability of relations between countries. [1]. Besides, historically, the science of international relations started from a discussion of why wars occurred and how to create peace [2]. Therefore, understanding the basic concepts of security is crucial for international relations students.

The three methods that have been applied previously are Student Team Achievement Division (STAD), Small Group Discussion (SGD), and lectures that require faceto-face meetings that are dominant in every learning process. Meanwhile, in today's era of technological development, the world demands a flexible type of learning in terms of time, place, and circumstances. Therefore, it is necessary to do the renewal, namely by applying information technology that utilizes virtual communication so that students can comfortably study anytime and anywhere [3].

Besides, because this class is a compulsory class, the number of students taking this course in one class is almost 70 people. This makes it difficult for lecturers to monitor student development one by one when using conventional methods.

We argue that the video presentation technique will help students more easily understand the meaning of the concepts being taught. This paper aims to find out what is the technical application of learning using video presentations and virtual brainstorming in explaining the concepts of security to International Relations student of Universitas Andalas. 


\subsection{Previous Research}

The use of audio-visual material is actually not new, because it has been applied as a training tool for soldiers during the Second World War [4]. So that from the past the benefits of using video as a learning medium have been recognized. According to Griffin, the main goal of an educator is for students to be involved and get a learning experience as expected, the more interactive the techniques used, the more students will enjoy and get a lot of information through this learning [5].

Zemsky and Massey also concluded that students prefer learning using digital technology due to three things. First, by using digital media they can easily connect with each other, second, students like entertainment through music and videos and the third reason is because they are freer to express their opinions using digital platforms rather than face to face. [6].

Mohammed Ibrahim in his research found that by presenting a video presentation the results obtained were superior to learning using traditional method. [7].

June, Yaacob and Khar Keng also found the same thing in their research entitled "Assessing the Use of Youtube Videos and Interactive Activities as A Critical Thinking Stimulator for Ertiary Students: An Action Reserach". Students are considered to be more participant and this technique is able to improve critical thinking from students. Youtube videos are an effective tool to stimulate learning and critical thinking from students [8].

Based on the previous studies above, it can be concluded that the use of learning techniques using video has a positive impact on learning outcomes.

\section{METHODS}

\subsection{The Design of this Study}

This research is an experimental study consisting of a pre-test and post-test as well as a questionnaire. This design was chosen with the aim of testing the effectiveness of the learning technique using video. The population of this study were all students of International Relations at Andalas University who took the Security Studies and Strategy course in this semester (140 students) which consisted of two classes, namely classes $\mathrm{A}$ and $\mathrm{B}$.

\subsection{Research Instrument}

\subsubsection{The Pre-Test dan Post Test}

The pre-test and post-test consist of 9 multiple choice questions related to the main concepts in safety studies:

\section{Deterrence}
2. Nuclear Proliferation
3. Security Dilemma
4. Warfare
5. Bandwagoning
6. Buck-passing
7. International Cooperation
8. Dependency and interdependency
9. Arm race

\subsubsection{Questionnaire}

After the post-test, students are asked to fill out a questionnaire containing 5 questions regarding the effectiveness of learning media using video, here is a questionnaire distributed to students:

Tabel 2.1 Questionnaire on the Effectiveness of Video Presentation Techniques in Learning Security Concepts

\begin{tabular}{|c|c|c|c|c|}
\hline No & Question & 1 & 2 & 3 \\
\hline 1. & $\begin{array}{l}\text { Learning using video is } \\
\text { more interactive }\end{array}$ & & & \\
\hline 2. & $\begin{array}{l}\text { It is easier for me to } \\
\text { remember the meaning } \\
\text { of the concept through } \\
\text { the video explanation. }\end{array}$ & & & \\
\hline 3. & $\begin{array}{l}\text { Videos help me in } \\
\text { recalling materials at } \\
\text { home }\end{array}$ & & & \\
\hline 4. & $\begin{array}{l}\text { I can study whenever I } \\
\text { want }\end{array}$ & & & \\
\hline 5. & $\begin{array}{l}\text { I can give more } \\
\text { expressive criticism and } \\
\text { feedback regarding the } \\
\text { material }\end{array}$ & & & \\
\hline
\end{tabular}

\section{RESULT AND DISCUSSION}

This study found that based on the comparison between the pre-test and post-test, it was clear that the scores had a significant increase in students' understanding of security concepts.

Tabel 3.1 Comparison of Pre-Test and Post-Test results

\begin{tabular}{|l|l|c|c|}
\hline No & Skor & Pre-Test & Post-Test \\
\hline 1. & 90 & 0 & 82 \\
\hline 2. & 80 & 0 & 34 \\
\hline 3. & 70 & 4 & 22 \\
\hline 4. & 60 & 30 & 2 \\
\hline 5. & 50 & 44 & 0 \\
\hline 6. & 40 & 26 & 0 \\
\hline 7. & 30 & 16 & 0 \\
\hline 8. & 20 & 10 & 0 \\
\hline 9. & 10 & 10 & 0 \\
\hline 10. & 0 & 0 & 0 \\
\hline
\end{tabular}

The data above shows that around $58.57 \%$ of the total 140 students managed to answer all questions correctly 
after watching the video that was uploaded to the YouTube account. Meanwhile, in the pre-test it was found that only about $2.8 \%$ of the students managed to understand the 7 concepts correctly.

Figure 3.1 Student Opinions on the Benefit of Video as a Learning Media

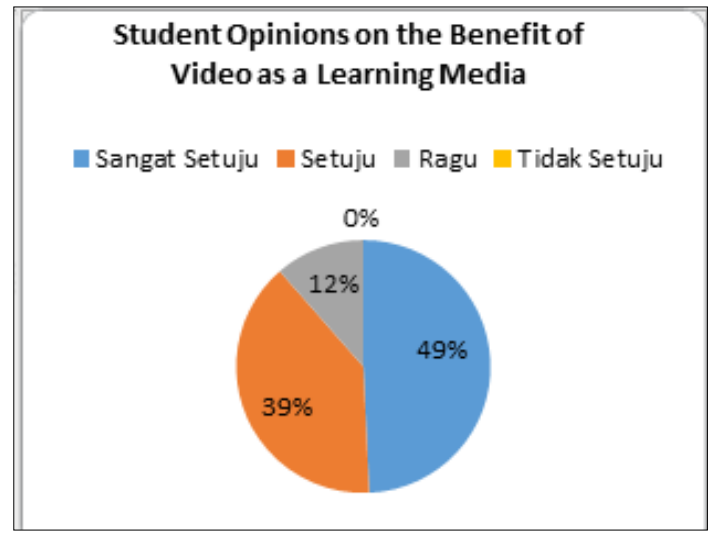

The results of the questionnaire show that around $88 \%$ of students think that learning the concept of security is easier if you use video.

Besides increasing student knowledge regarding the concept of security, this technique is also considered to be able to improve students' ability to better express their thoughts. From the questionnaires distributed to 140 students, 73 students thought that this technique made them more flexible to express their opinions through virtual communication. This is because students who have a low level of selfconfidence will be greatly helped to convey their opinions without having to be afraid of being the center of attention.

Another advantage of this video learning technique is that students can access the material anytime and anywhere, so the learning process becomes more flexible and fun. This can be an alternative to the learning process that cannot be done face-to-face like the current Covid 19 phenome. A more interactive display is also a special attraction for students. This is because since childhood the current generation has been accustomed to audio-visual media such as TVs, laptops and other gadgets. So that this then has an impact on the way students learn. Their tendency is to be more bored reading material in the form of text that contains only visuals, or to be bored when listening to lecturers' lectures in class. This technique is also more effective for online lectures when compared to teleconferences via zoom platforms and google meet and others. First, the costs incurred for students to access videos on YouTube are much cheaper than teleconferences. Second, teleconferencing demands a stable internet network, if suddenly the signal is lost, students will miss some materials. Third, although meetings via zoom or other platforms can be recorded, the file size is much larger and also the appearance is not as attractive as a video presentation where music can be added as a backgorund and there is animation.

However, the weakness of this technique is based on the experiments that have been carried out, the lecturer will need more time to prepare the class. Because there are several steps that must be done such as preparing materials, making videos, editing videos, recording sound and then exporting the videos and the last step is uploading videos to the YouTube channel. This time consuming process may be burdensome for lecturers. In addition, lecturers are also required to have the ability to make and edit videos to produce interactive learning videos.

\section{CONCLUSION}

This study concludes that the video presentation technique is effective in learning the basic concepts of security for international relations students at Andalas University. This is evident from the post-test that has been carried out where nearly $60 \%$ of students get perfect scores. Besides, the opinions of students who were collected through a questionnaire also showed that the research subjects agreed that the video learning technique made it easier for them to understand the material. The suggestions that can be offered based on this research are the need for training for lecturers in making and editing videos, so that the results of the learning videos become more interactive and increase students' enthusiasm for learning.

\section{.ACKNOWLEDGMENTS}

This study is supported by the Institute for Educational Development and Quality assurance Universitas Andalas.

\section{REFERENCES}

[1] Preece, J.Jackson, Security in International Relations, University of London International Program, 2011.

[2] Martín, Félix E. "CRITICAL ANALYSIS OF THE CONCEPT OF PEACE IN INTERNATIONAL RELATIONS." Peace Research 37, no. 2 (2005): 4559. Accessed October 24, 2020. http://www.jstor.org/stable/23607773.

[3] Wiana, Winwin, et all, The Effectiveness of Using Interactive Multimedia Based on Motion Graphic in Concept Mastering Enhancement and Fasion Designing Skill in Digital Format, International Journal of Emerging Technologies in Learning, Vol 13, No,2, https://doi.org/10.3991/ijet.v13i02.7830.

[4] Hovland, C.I., Lumsdaine, A.A. \& Sheffield, F.D. (1949). Experiments on masscommunication. Princeton, NJ: Princeton University Press.

[5] Griffin, L. (2008). Using Video in the Classroom, Libraryvideo.com, Retrieved on 24 October from http://www.libraryvideo.com/articles/article13.asp.

[6] Zemsky, R. and Massey, W. F. (2004) "Why the ELearning Boom Went Bust," Chronicle of Higher Education,Vol. 50.

[7] Ibrahim, Mohammed, The Effectiveness of Video Presentation Techniques on Learning of Grammatical Structures among Senior Secondary School Students in Sokoto State, Nigeria, Journal of Education and Practice, Vol 4 No 16, 2013. 
[8] June, S, Yacoob, A, Kheng, Yeoh Khar, Assessing the Use of Youtube Videos and Interactive Activities as a Critical Thinking Stimulator for Tertiary Students: An Action Research, International Education Studies Vol 7 No 8, 2014, doi:10.5539/ies.v7n8p56 